\title{
Positive Effects of a Four-Week Rehabilitation Spa Program on Quality of Life in Patients with Ankylosing Spondylitis
}

\author{
Dušan Mustur \\ Institute Igalo, Igalo, Montenegro
}

SUMMARY

This is an open uncontrolled study about the positive effects of a four-week rehabilitation spa program on the quality of life of 74 patients with ankylosing spondylitis. We assessed the following health status parameters on admission and discharge from the Institute Igalo, Montenegro: BASFI, BASDAI, ASDAS-CRP, ASAS 20 improvement criteria and SF-36 questionnaire. It was a "test-retest study". All the patients had six days of spa physical therapy per week during the four-week rehabilitation program, which made 24 therapy days in total. Therapy sets included the exercise program in gym and pool with mineral water, breathing exercises, massage therapy, balneotherapy (mud packs of baths, mineral and pearl baths, underwater massages), electrotherapy, sonotherapy, as well as thalassotherapy. Physiotherapy was prescribed by physician individually according to general health status and eventual contraindications. In all the observed parameters, statistical analysis showed that there was a highly significant improvement $(p<0.01)$. After four weeks of spa rehabilitation, ASAS 20 improvement index was achieved in $74.3 \%$ of patients with ankylosing spondylitis. Conclusions were that four weeks of complex spa physical therapy program in Institute Igalo led to a significant improvement of assessed parameters of disease activity, functional status and in domains of quality of life.

Key words: ankylosing spondylitis, quality of life, spa physical therapy

Corresponding author:

Dušan Mustur

e-mail:dusanm@ucg.ac.me 


\section{INTRODUCTION}

Rehabilitation of patients suffering from ankylosing spondylitis (AS) is a lifelong process. It should consider a complete medical care from the appearance of first symptoms, both in active phase and in remission, how to make a full adaptation of a patient to a disease and joints damages, and to have an active life as much as possible. In that way, rehabilitation becomes prevention too, not only something to consider when other medical approaches have been done. This approach is named a total care or complete management of a patient. With a total care and early rehabilitation, percentage of complete disability in AS is reduced from $25 \%$ to only $1 \%$.

The main goal of rehabilitation is to achieve full functional independence and good quality of life in patients with AS. Medical rehabilitation can be divided into three levels: the first level is the prevention of a disease progression; the second level is a reduction of functional disability, whereas the third level covers the use of different types of orthoses and other measures to prevent joint contractures and bad body posture.

Spa rehabilitation program in AS includes kinesiotherapy both in a gym and a pool, balneology complex (mud packs of baths, mineral and pearl baths, underwater massages), massage therapy, electrotherapy, sonotherapy, as well as thalassotherapy. Spa therapy is commonly used in the treatment of patients suffering from AS, but its benefits are still the subjects of discussion. The goal of this study was to evaluate effects of a complex spa and physical therapy program on functional disability, disease activity and complete quality of life in patients with ankylosing spondylitis.

\section{PARTICIPANTS AND METHODS}

This study enrolled 74 adult patients with diagnosed ankylosing spondylitis, and it was done at the Institute Igalo, Montenegro, during September and October, which is climatically the mildest period of the year. The modified New York criteria for AS were applied and only those patients which had definite radiographic sacroiliitis (bilateral sacroiliitis $\geq$ grade 2 or unilateral sacroiliitis $\geq$ grade 3 ) were accepted as AS. The exclusion criteria were patients who had other rheumatic disease, as well as juvenile AS. The study was approved by the Medical Ethics Committee at the School of Medicine, University of
Belgrade. Responders were informed of the reason of this study and a written informed consent was obligatory prior to testing from all patients with AS.

Kinesiotherapy program consisted of breathing exercises, relaxation, correction of a body posture, muscle imbalance and strength, but also mobilization of a spine, stretching and a group exercises in pool. Electrotherapy procedures (interference currents or diadynamic currents) were prescribed to get the analgesic effect: to reduce pain and muscle stiffness. Thalassotherapy represents the organized application of natural factors in the sea area: climate, sun, aerosol, wind, sea water, sea peloid/mud, sand.

All patients had four weeks of spa physical treatment that included a balneological complex and exercise program six days a week, or a total of 24 days of treatment. A group of patients served as its own control, so all the observed data were obtained on admission and discharge. All participants maintained the same dosage of a non-steroidal antiinflammatory drugs (NSAID), synthetic disease modifying anti-rheumatic drugs (sDMARD) and/or a biological medications (BA) during a four-week spa program.

To assess quality of life in patients with AS, a specific tool was developed, the so-called The Ankylosing Spondylitis Quality of Life (AS-QoL). Still, the most widely used generic instrument to assess quality of life in patients with different diseases is the Medical Outcomes Study Short Form 36-Item Questionnaire (SF-36). This questionnaire is considered as a "golden standard" in quality of life assessment in different diseases. SF-36 has been used to measure the health-related quality of life in thousands of research studies (1). The questionnaire includes 36 questions, of which 35 questions refer to the health status in the previous four weeks, and one question shows a change in the health status in relation to the period of 12 months ago. This questionnaire reflects eight domains of a Health-Related Quality of Life: Physical Function, Physical Role, Bodily Pain, General Health, Vitality, Social Function, Emotional Role and Mental Health. The scores are coded and then transformed into the eight $0-100$ scales, where 0 means worst and 100 means the best possible quality of life. It takes around 10 minutes to complete this questionnaire (2).

Functional disability in patients with AS can be assessed with different questionnaires: Bath Ankylosing Spondylitis Functional Index (BASFI), Health Assessment Questionnaire for Spondylo- 
arthritis (HAQ-S) or Dougados Functional Index (DFI). In this study we used BASFI to measure the severity of functional abilities, scored on visual analog scale (VAS) of $0-10$, with 0 as "easy" and 10 as "impossible". Eight questions in BASFI relate to the following activities of daily life: put on socks, pick up pen from the floor, reach a high shelf, get up from a chair, get up from the lying position, standing without support for 10 minutes or more, climb 12 15 stairs, look over the shoulder, and two questions relate to how patient performed demanding activities and full day's activities during the last week. The total score from all 10 items is divided by 10 for the final score, so a higher score of BASFI means the worst functional status.

Bath Ankylosing Spondylitis Disease Activity Index (BASDAI) measures the severity of symptoms during the last week, scored on VAS of 0 - 10, with 0 as "without any symptom" and 10 as "very severe". Four questions in BASDAI relate to the severity of symptoms of fatigue, pain in the neck, back and hips, pain in other joints, and discomfort in areas that are tender to touch or pressure. To score BASDAI, we should take the sum of those four questions and then add the mean of intensity of morning stiffness (on VAS of $0-10$ ) and duration of morning stiffness from 0 minutes up to 2 hours or more, scored on 0 - 10 scale. Finally, we have to divide the total sum by five to get the final score of index BASDAI, where a higher score means more disease activity.

Ankylosing Spondylitis Disease Score (ASDAS) was our most precise clinical tool to assess the disease activity in patients with AS (3). This score have two formulas: the first one is preferred and includes C-reactive protein (CRP), and alternative formula includes erythrocyte sedimentation rate (ESR). ASDAS-CRP measures the severity of symptoms and signs of inflammation, including the duration of morning stiffness, back pain, patient global and peripheral pain and swelling, as well as CRP level. The score can be calculated using the online ASDAS calculator. ASDAS-CRP score $<1.3$ means inactive disease (remission), between 1.3 and 2.1 is low disease activity of AS, between 2.1 and 3.5 high disease activity, and more than 3.5 means very high disease activity.

Assessment in ankylosing spondylitis (ASAS) improvement criteria are commonly used in different studies. ASAS improvement requires improvement in five areas relevant to disease outcome: patient global assessment of AS over the past week (on VAS $0-100 \mathrm{~mm}$ ), pain (combination of total back pain and nigh back pain) over the past week (VAS 0$100 \mathrm{~mm}$ ), functional impairment assessed by BASFI (0 - 100), duration of morning stiffness (in minutes) and fifth is not to have worsening in any of the remaining measures. The use of different biological agents often provides ASAS 40 improvement, however, we wanted to investigate in how many patients we can achieve ASAS 20 improvement only with a four-week program of spa physical therapy.

\section{RESULTS}

Participants in this study were aged between 26 and 70 years (mean $48.5 \pm 10.3$ ). The average time since the diagnosis of AS was $15.2 \pm 8.8$ years (range from 1-33 years), and average delay (time from first symptoms to diagnosed AS) was $8.9 \pm 0.9$ years (range from 7 - 12 years). There were 58 men (78\%) and 22 women $(22 \%), 24$ of them were tobacco users $(32.4 \%)$ and $50(67.6 \%)$ were not tobacco users or they quit smoking at least a month before this study started (Table 1). Human leucocyte antigen B27 (HLA B27) positive were $66(89.2 \%)$ patients, and 8 $(10.8 \%)$ patients were negative. Positive family history of arthritis was present in 44 participants $(59.5 \%)$ and 30 of them $(40.5 \%)$ had negative family history of arthritis (or could not remember anybody in family with arthritis).

Table 1. Demographic characteristics: sex, smoking cigarettes, family history of arthritis, HLA B27 antigen

\begin{tabular}{l|c|c}
\hline \hline Participants & $\mathrm{F}$ & $\%$ \\
\hline Sex (male/female) & $58 / 16$ & $78 / 22$ \\
\hline Tobacco users (active smoking/ex or no smoking) & $24 / 50$ & $32.4 / 67.6$ \\
\hline Family history of arthritis (yes/no) & $44 / 30$ & $59.5 / 40.5$ \\
\hline HLA B27 antigen (positive/negative) & $66 / 8$ & $89.2 / 10.8$ \\
\hline \hline
\end{tabular}




\section{Disease activity and functional status assessment}

The average score of BASDAI on admission was $4.3 \pm 1.6$ (from 0.9 to 8.2 ), on discharge it fell to $1.9 \pm 1.3$ (from 0.1 to 5.3 ) (Table 2). Statistical analysis showed that there was a highly significant reduction of a disease activity $(\mathrm{p}<0.01)$.

BASFI score at the beginning of spa physical treatment was $3.9 \pm 2.0$ (from 1.4 to 7.7). After four weeks, it dropped down to $1.7 \pm 1.3$ (from 0.5 to 4.9 ). Statistical analysis showed that there was a highly significant improvement in the functional status in patients with AS $(p<0.01)$.

The average score of ASDAS-CRP on admission was $3.9 \pm 1.6$ (from 0.9 to 5.3 ), and on discharge it dropped to $1.3 \pm 1.2$ (from 0.6 to 3.2 ). Statistical analysis showed that there was a highly significant reduction of a disease activity $(p<0.01)$.

After four weeks of spa physical treatment at the Institute Igalo in Montenegro, ASAS 20 improvement index was achieved in 55 of 74 patients with AS (74.3\%) (Table 3).

Table 2: Disease activity and functional status indices before and after spa physical therapy

\begin{tabular}{l|c|c|c|c|c|c|c|c}
\hline \hline & \multicolumn{6}{|c|}{ Before Spa Physical Therapy } & \multicolumn{5}{|c}{ After Spa Physical Therapy } \\
\hline & $x$ & $S D$ & Range & $x$ & $S D$ & Range & $t$ & $P$ \\
\hline BASDAI & 4.3 & 1.6 & $0.9-8.2$ & 1.9 & 1.2 & $0.1-5.3$ & 14.348 & $<0.01$ \\
\hline BASFI & 3.9 & 2.0 & $1.4-7.7$ & 1.7 & 1.3 & $0.5-5.3$ & 12.017 & $<0.01$ \\
\hline ASDAS-CRP & 3.9 & 1.6 & $0.9-5.3$ & 1.3 & 1.2 & $0.6-3.2$ & 14.746 & $<0.01$ \\
\hline \hline
\end{tabular}

Table 3: ASAS 20 after four weeks of spa physical therapy in Igalo

\begin{tabular}{c|c|c}
\hline \hline & $\mathrm{f}$ & $\%$ \\
\hline ASAS 20 improvement & $55 / 19$ & $74.3 / 25.7$ \\
\hline \hline
\end{tabular}

\section{Quality of life assessment}

Health-related quality of life was estimated by the Medical Outcomes Short Form 36 items questionnaire (SF-36) two times: at beginning and after four weeks of a complex spa physical treatments. Results of the observed eight domains of quality of life are the following:

Physical function is a domain that includes 10 questions related to the possibility of performing various physical activities during one average day as well as the level of limitation in those activities caused by the disease. These activities are as follows: strenuous activities (running, lifting heavy objects, participating in strenuous sports); moderately difficult activities (riding a bicycle, moving the table, pushing a vacuum cleaner, working in the garden); lifting or carrying things; climbing upstairs; bending, squatting; walking abilities; self-care (independent bathing and dressing). The average score of Physical Function domain was on admission $42.3 \pm 7.0$ (range 19.4-55.0), while on discharge it was improved to
$49.2 \pm 6.2$ (from 27.8 to 57.1). Statistical analysis showed that there was a highly significant difference $(p<0.01)$ in physical functioning on discharge compared to the condition on admission (Table 4).

Physical role, involving limitations in usual role activities because of physical health problems, is a dimension of a SF-36 questionnaire that includes four questions about the existence of problems in performing work or other regular activities due to the impaired physical health of the respondents. The average score of Physical Role on admission was 37.7 \pm 8.0 (from 28.0 to 56.2). On discharge, it raised up to $50.3 \pm 6.9$ (from 35.0 to 56.2). Statistical analysis showed that there was a highly significant improvement $(\mathrm{p}<0.01)$ in physical role on discharge (Table 4$)$.

Bodily pain consists of two questions. The first one concerns the presence of body pain and how strong it was during the last four weeks; the second one is about the influence of pain on usual daily activities at home and outside. The average score of 
Table 4. Results of SF-36 questionnaire

\begin{tabular}{l|c|c|c|c}
\hline \hline \multicolumn{1}{c|}{ SF-36 } & Before spa treatment & \multicolumn{3}{|c}{ After spa treatment } \\
\hline & $\mathrm{X} \pm \mathrm{SD}$ & $\mathrm{X} \pm \mathrm{SD}$ & $\mathrm{t}$ & $\mathrm{p}$ \\
\hline Physical function & $42.3 \pm 7.0$ & $49.2 \pm 6.2$ & -15.812 & $<0.01$ \\
\hline Physical role & $37.7 \pm 8.0$ & $50.3 \pm 6.9$ & -14.081 & $<0.01$ \\
\hline Bodily pain & $36.3 \pm 6.5$ & $48.3 \pm 6.8$ & -15.228 & $<0.01$ \\
\hline Vitality/Energy & $42.2 \pm 8.5$ & $55.8 \pm 7.5$ & -12.060 & $<0.01$ \\
\hline Social function & $38.7 \pm 8.2$ & $50.2 \pm 6.4$ & -14.087 & $<0.01$ \\
\hline Emotional role & $41.7 \pm 11.7$ & $52.6 \pm 6.0$ & -8.951 & $<0.01$ \\
\hline Mental health & $44.8 \pm 8.8$ & $58.2 \pm 6.2$ & -16.395 & $<0.01$ \\
\hline General health & $37.2 \pm 8.5$ & $47.5 \pm 8.5$ & -12.327 & $<0.01$ \\
\hline \hline
\end{tabular}

Bodily Pain on admission was $36.3 \pm 6.5$ (from 19.9 to 51.6). On discharge, the score raised up to $48.3 \pm 6.8$ (from 33.6 to 62.7 ). Statistical analysis showed that there was a highly significant difference $(p<0.01)$ in Bodily Pain on discharge (Table 4). We emphasize that a higher score of this dimension means a better quality of life of the responders (a lower level of physical pain).

Vitality (energy and fatigue) is a fourth dimension of the SF-36 questionnaire. It involves 4 questions about how responders felt during the previous four weeks (full of life, energized, tired, exhausted). The average score of Vitality/Energy domain on admission was $42.2 \pm 8.5$ (range 23.0 - 60.9) Despite hard spa physical treatment, it improved to $55.8 \pm 7.5$ (from 32.5 to 70.4) on discharge. Statistical analysis showed that there was a highly significant difference $(p<0.01)$ in vitality on discharge compared to the condition on admission (Table 4).

Social function consists of two questions about limitations in social activities because of physical or emotional problems during the previous four weeks. The average score of Social Function domain was on admission $38.7 \pm 8.2$ (range $13.7-57.1$ ), and it improved to $50.2 \pm 6.4$ (from 35.4 to 57.1 ) on discharge. Statistical analysis showed that there is a highly significant difference $(\mathrm{p}<0.01)$ in social functioning on discharge compared to the condition on admission (Table 4).

Emotional Role is a sixth domain and it consists of 3 questions about limitations in usual role activities at home or at work because of emotional problems during the last four weeks. The average score of Emotional Role domain was on admission $41.7 \pm 11.7$ (range 23.7 - 55.3), while it improved to
$52.6 \pm 6.0$ (from 23.7 to 55.3 ) on discharge. Statistical analysis showed that there was a highly significant difference $(p<0.01)$ after four weeks of spa physical therapy program (Table 4 ).

Mental Health involves five questions about psychological distress and wellbeing (nervousness, fatigue, depression...) and for how long it is present. The average score of this domain was on admission $44.8 \pm 8.8$ (range $16.4-59.5$ ), and it improved to 58.2 \pm 6.2 (from 34.5 to 64.1 ) on discharge. Statistical analysis showed that there was a highly significant improvement in mental health $(\mathrm{p}<0.01)$ on discharge (Table 4).

General Health is the last domain of SF-36 questionnaire that has also five questions. Questions are about patient's perception of their general health now and their immune system. The average score of this domain was on admission $37.2 \pm 8.5$ (range 17.2 57.9), whereas on discharge it improved to $47.5 \pm 8.5$ (from 28.9 to 62.6). Statistical analysis in this domain also showed a highly significant improvement $(\mathrm{p}<$ 0.01 ) in general health on discharge compared to the condition on admission (Table 4).

\section{DISCUSSION}

Physical treatment has shown to have a very important role in the management of the ankylosing spondylitis, even in the era of biological medications $(4,5)$. The most important part of physical therapy in patients with AS are exercises. The main goals of individually planned exercise program is to reduce pain, reduce morning stiffness, increase functional capacity, muscle strength and spinal mobility, correct posture of patients with AS, increase general 
mobility and improve psychosocial status and quality of life of those patients. Breathing exercises with the "chest type" of breathing (inhale on nose, exhale on mouth) are very important in patients with AS (6).

Levitova A et al. found that ASDAS-CRP score significantly decreased $(p<0.01)$ even after six months of exercise program. Additionally, there was a trend of decline in the BASDAI score $(p=0.06)$, but not in the BASFI score after six months of training (7). A meta-analysis of randomized controlled trials has shown effectiveness of exercise programs on disease activity (measured by BASDAI) and functional status (measured by BASFI) in patients with AS (8). BASDAI does not include a biomarker of inflammation (CRP), but many studies have shown that it highly correlates with ASDAS-CRP $(9,10)$.

Similar to the results of our study, Lubrano et al. found that ASAS 20 improvement was achieved in $88.5 \%$ at the end of a three-week intensive rehabilitation program in patients with AS (11).

Health-related quality of life of patients with AS is significantly reduced in all domains of SF-36 questionnaire compared to the general population (12).

There is additional contribution of spa balneotherapy on physical therapy in AS $(13,14)$. Also, a study of Kjeken I et al. showed that a three-week multidisciplinary in-patient rehabilitation program had positive long-term effects in patients with ankylosing spondylitis. A significant effects has been found in the BASDAI score and in the SF-36 variables such as physical role, mental role, vitality and bodily pain after 4 months, but not in the BASFI score. They found no significant differences in any outcome of SF-36 after 12 months when they compared a three-week rehabilitation program to selfmanagement in terms of physical activity and exercises (15).

The study of Staalesen Strumse YA, et al. in- dicates positive effects of a four-week rehabilitation spa program for patients with AS performed either in the Mediterranean or in Norwegian setting. All the observed parameters improved significantly after the programme was done (BASDAI score, BASFI score, etc.) but remained even three months after spa treatment was finished. Improvements in the health status were larger in the group of patients that had rehabilitation in a Mediterranean country rather than in Norway. The immediate efficacy of ASAS 20 improvement (79\%) in the Mediterranean group was similar to our findings. ASAS 20 was present even 16 weeks after the program was finished in $50 \%$ of patients with AS in the Mediterranean group (16).

\section{CONCLUSIONS}

Physical therapy plays a central role in the overall management of patients suffering from AS. However, a complex spa rehabilitation four-week program that includes balneotherapy leeds to a significant reduction of the disease activity (measured by BASDAI and ASDAS-CRP), improvement of a functional status (measured by BASFI score); it significantly improves the health status (ASAS 20) and improves all the observed segments of Quality of Life of SF-36 m questionnaire. As in other studies, certain limitations and ranges were observed in this study. The biggest limitation is that after four weeks of spa rehabilitation treatment, AS patients left Igalo Spa, which made further communication much more difficult and led to lack of information about health status and quality of life three and more months after physical therapy was finished. The duration of the effects of the spa rehabilitation program depends not only on the duration and type of physical procedures but also on the spa resorts themselves. More studies will be needed to address this issue. 


\section{References}

1. Lins L, Carvalho FM. SF-36 total score as a single measure of health-related quality of life: Scoping review. SAGE Open Med. 2016;4:1-12 https://doi.org/10.1177/2050312116671725

2. Medical Outcomes Trust Editors. How to Score the SF-36 Health Survey (SF-36). Boston Medical Outcomes Trust, 1994.

3. Zochling J. Measures of symptoms and disease status in ankylosing spondylitis: Ankylosing Spondylitis Disease Activity Score (ASDAS), Ankylosing Spondylitis Quality of Life Scale (ASQoL), Bath Ankylosing Spondylitis Disease Activity Index (BASDAI), Bath Ankylosing Spondylitis Functional Index (BASFI), Bath Ankylosing Spondylitis Global Score (BAS-G), Bath Ankylosing Spondylitis Metrology Index (BASMI), Dougados Functional Index (DFI), and Health Assessment Questionnaire for the Spondylarthropathies (HAQ-S). Arthritis Care Res (Hoboken). 201;63 Suppl 11:S47-58.

https://doi.org/10.1002/acr.20575

4. Dagfinrud H, Kvien TK, Hagen KB. Physiotherapy interventions for ankylosing spondylitis. Cochrane Database Syst Rev. 2008; 23(1). Art. No.: CD002822.. Accessed 06 September 2021 https://doi.org/10.1002/14651858.CD002822.pub3

5. Lubrano E, D'Angelo S, Spadaro A et al. Rehabilitation for ankylosing spondylitis in the era of biologics: any room left for this treatment? J Rheumatol. 2011;38(7): 1228-30.

https://doi.org/10.3899/jrheum.110362

6. Dragoi RG, Amarical E, Dragoi $M$ et al. Inspiratory muscle training improves aerobic capacity and pulmonary function in patients with ankylosing spondylitis: a randomized controlled study. Clin Rehabil. 2016;30(4):340-6. https://doi.org/10.1177/0269215515578292

7. Levitova A, Hulejova H, Spiritovic M et al. Clinical improvement and reduction in serum calprotectin levels after an intensive exercise programme for patients with ankylosing spondylitis and nonradiographic axial spondyloarthritis. Arthritis Res Ther. 2016 25;18(1):275.

https://doi.org/10.1186/s13075-016-1180-1

8. Pecourneau V, Degboe $\mathrm{Y}$, Barnetche $\mathrm{T}$ et al. Effectiveness of Exercise Programs in Ankylosing Spondylitis: A Meta-Analysis of Randomised Controlled Trials. Arch Phys Med Rahabil. 2018;99(2):383-9.

https://doi.org/10.1016/j.apmr.2017.07.015

9. Lukas C, Landewe R, Sieper J et al. Development of an ASAS-endorsed disease activity score (ASDAS) in patients with ankylosing spondylitis. Ann Rheum Dis 2009; 68: 18-24. https://doi.org/10.1136/ard.2008.094870

10. $\mathrm{Xu} \mathrm{M}$, Lin $\mathrm{Z}$, Deng $\mathrm{X}$ et al. The Ankylosing Spondylitis Disease Activity Score is a highly discriminatory measure of disease activity and efficacy following tumour necrosis factor-alpha inhibitor therapies in ankylosing spondylitis and undifferentiated spondyloarthropathies in China. Rheumatology (Oxford) 2011; 50: 1466-72. https://doi.org/10.1093/rheumatology/ker087

11. Lubrano E, D'Angelo S, Parsons WJ et al. Effectiveness of rehabilitation in active ankylosing spondylitis assessed by the ASAS response criteria. Rhheumatology (Oxford). 2007;46(11):1672-5.

https://doi.org/10.1093/rheumatology/kem247

12. Dagfinrud H, Mengshoel AM, Hagen KB et al. Health status of patients with ankylosing spondylitis: a comparison with the general population. Ann Rheum Dis. 2004;63(12):1605-10. https://doi.org/10.1136/ard.2003.019224

13. Karagulle M, Kardes S, Karagulle MZ. Real-Life effectiveness of spa therapy in rheumatic and musculoskeletal diseases: a retrospective study of 819 patients. Int J Biometeorol. 2017;61(11):1945-56. 
https://doi.org/10.1007/s00484-017-1384-3

14. Cozzi F, Ciprian L, Carrara M et al. Balneotherapy in chronic inflammatory rheumatic diseases-a narrative review. Int J Biometeorol. 2018;62(12):206571. https://doi.org/10.1007/s00484-018-1618-z

15. Kjeken I, Bø I, Rønningen A et al. A three-week multidisciplinary in-patient rehabilitation programme had positive long-term effects in patients with ankylosing spondylitis: randomized controlled trial. J Rehabil Med. 2013;45(3):260-7. https://doi.org/10.2340/16501977-1078

16. Staalesen Strumse YA, Nordvag BY, Stanghelle JK et al. Efficacy of rehabilitation for patients with ankylosing spondylitis: comparison of a four week rehabilitation programme in a Mediterranean and a Norwegian setting. J Rehabl Med. 2011;43(6):534-42. https://doi.org/10.2340/16501977-0804

\title{
Pozitivni efekti četvoronedeljnog rehabilitacionog banjskog programa na kvalitet života bolesnika sa ankilozirajućim spondilitisom
}

\author{
Dušan Mustur \\ Institut Igalo, Igalo, Crna Gora
}

S A ŽETAK

Ovo je otvorena nekontrolisana studija o pozitivnim efektima četvoronedeljnog rehabilitacionog banjskog programa na kvalitet života kod 74 bolesnika sa ankilozirajućim spondilitisom. Procjenjivali smo sledeće parametre zdravstvenog stanja na prijemu i prilikom otpusta iz Instituta Igalo: BASFI, BASDAI, ASDAS-CRP, ASAS 20 kriterijume poboljšanja, kao i upitnik kvaliteta života SF-36. Bila je to "test-retest studija“. Svi pacijenti su imali šest dana banjskog fizikalnog liječenja sedmično tokom četiri sedmice programa rehabilitacije, što je ukupno predstavljalo 24 terapijska dana. Terapijski set je obuhvatao vježbe u sali i u bazenu sa mineralnom vodom, vježbe disanja, manuelne masaže, balneoterapije (blatne kupke, mineralne i biserne kupke, podvodne masaže), elektroterapije, sonoterapije, kao i talasoterapiju. Fizioterapijske procedure je propisivao ljekar individualno za svakog pacijenta ponaosob u skladu sa njegovim opštim zdravstvenim stanjem i eventualnim kontraindikacijama. U svim posmatranim parametrima statistička analiza pokazala je da postoji vrlo značajno poboljšanje $(p<0,01)$. Nakon četiri sedmice rehabilitacije, indeks poboljšanja ASAS 20 postignut je kod $74,3 \%$ pacijenata s ankilozirajućim spondilitisom. Zaključeno je da četiri sedmice kompleksnog banjskog programa fizikalne terapije u Institutu Igalo dovodi do značajnog poboljšanja svih ispitivanih pokazatelja aktivnosti bolesti, funkcionalnog stanja, kao i poboljšanja u svim domenima kvaliteta života.

Ključne reči: ankilozirajući spondilitis, kvalitet života, fizikalna terapija u banji 